\title{
Comparing Waterbeds and Sand Beds for Cows: A Study at the UF/IFAS Dairy Unit ${ }^{1}$
}

\author{
Klibs N. Galvão and Ori Eizenberg²
}

\section{Introduction}

The comfort of a dairy cow is extremely important to the cow's health and profitability. One important aspect of a cow's comfort is the type of bedding used. A USDA report (2009) listed the five main types of bedding used at large animal operations, including straw and/or hay (54.1\%), sawdust/wood products (35.0\%), rubber mats (30.2\%), mattresses (23.7\%), and sand (21.9\%). The report also listed the five main types of bedding used for lactating dairy cows, including straw and/or hay (33.4\%), sawdust/wood products $(31.2 \%)$, sand $(30.3 \%)$, compost manure $(24.2 \%)$, and mattresses (20.1\%). Sand beds are considered the gold standard for dairy cow bedding (Gomez and Cook 2010; Cook 2012). In this report, waterbeds were being used by only $1.7 \%$ of operations and only $2.3 \%$ of lactating dairy cows.

Waterbeds for cows have recently gained popularity because of advertisements, news reports in outlets such as CNN (http://eatocracy.cnn.com/2012/01/19/cows-on-waterbedscows-on-waterbeds-cows-on-waterbeds/), NBC (http:// www.kgw.com/lifestyle/Oregon-farms-try-out-waterbedsfor-cows-162663776.html), TIME magazine (http:// newsfeed.time.com/2012/07/19/cows-deserve-waterbedstoo/), and the Huffington Post (http://www.huffingtonpost. com/2012/05/29/cow-massage-waterbed_n_1552199.html), and recent research (Fulwider et al. 2007).
A Colorado University research team (Fulwider et al. 2007) evaluated hock lesions in 100 dairy herds from Wisconsin, Minnesota, Indiana, Iowa, and New York using rubberfilled mattresses (RFM; $n=38$ ), sand beds ( $n=27)$, waterbeds $(n=29)$, and compost packs $(n=6)$. The team observed that all cows in the compost pack herds were free of lesions. Furthermore, the researchers confirmed that cows on sand beds had fewer hock lesions than those on RFM, but observed that there were no differences between sand beds and waterbeds.

This study points to a couple of interesting questions: First, given that compost packs had the best hock scores, can they be a viable alternative to free stalls? Second, does the observation that waterbeds were not different than sand beds mean that waterbeds can be as good as sand beds, or that sand beds can be as bad as waterbeds? We raise these questions because in our experience in Florida, cows using well-designed and appropriately bedded stalls had minimal to no lesions. Also, the two herds using waterbeds in Florida had less stall usage and more hock lesions. These findings indicate that if stalls are not designed properly or if the amount of sand in the stall is not maintained at the appropriate level, sand beds could perform below expectations. The Colorado research team did mention that sand-bedded stalls were shorter and narrower; however, the results were not adjusted for the variable stall length.

1. This document is VM194, one of a series of the Department of Large Animal Clinical Sciences, College of Veterinary Medicine, Florida Cooperative Extension Service, Institute of Food and Agricultural Sciences, University of Florida. Original publication date May 2013. Visit the EDIS website at http:// edis.ifas.ufl.edu.

2. Klibs N. Galvão, DVM, MPVM, PhD, assistant professor, Department of Large Animal Clinical Sciences, College of Veterinary Medicine; and Ori Eizenberg, Bachelor of Arts in Business Administration with a Specialization in Animal Sciences; Florida Cooperative Extension Service, Institute of Food and Agricultural Sciences, University of Florida, Gainesville, FL 32611. 
The UF/IFAS Dairy Unit (DU) provides a good opportunity to compare sand beds and waterbeds at optimal conditions. The dairy has waterbeds installed in one half of the barns and sand beds in the other half. Therefore, the objective of this publication is to provide a field comparison of waterbeds and sand beds in one herd.

\section{Materials and Methods}

\section{Study Herd}

The UF/IFAS DU was used for this observational study. At the research unit, approximately 500 Holstein cows are milked, with a rolling herd average of approximately 10,000 $\mathrm{kg}$ of milk. Cows were milked two times daily starting at 6 a.m. and 6 p.m., and total time spent away from the housing pen was limited to two hours a day. Cows were housed in four-row free-stall barns (Figure 1) with head-to-head design and a center drive through the feed alley. Each barn contained four pens under a 4/12-pitch roof (Figure 2). The free stalls were designed with open forward lunge, cantilever dividers, and a lying surface of 49 inches wide by 7 feet long. The neck rail was 6 feet from the curb, and the sand-bedded stalls had a brisket board that was 6 feet, 2 inches from the curb.

Cows were cooled using large droplet/low-pressure sprinklers above the feeding alley, fans above the feeding alley and beds, and small droplet/high-pressure misters mounted in the center of fans. The cooling system was activated whenever ambient temperature reached above $68^{\circ} \mathrm{F}$. A total mixed ration was delivered twice daily onto a flat, concrete feed apron, and feed was pushed up 12 times daily. Pens 1 , 2,6 , and 8 (Figure 1) were used. Pens 1 and 2 had deep-stall sand bedding (Figure 3), and pens 6 and 8 had waterbeds top-bedded with sand (Figure 4). All pens were re-bedded twice a week. Cows lying in sand (Figure 5) and waterbeds (Figure 6) can be observed. During the study, Pen 1 (94 stalls) housed 84 cows; Pen 2 ( 92 stalls) housed 95 cows; Pen 6 (82 stalls) housed 81 cows; and Pen 8 (80 stalls) housed 80 cows.

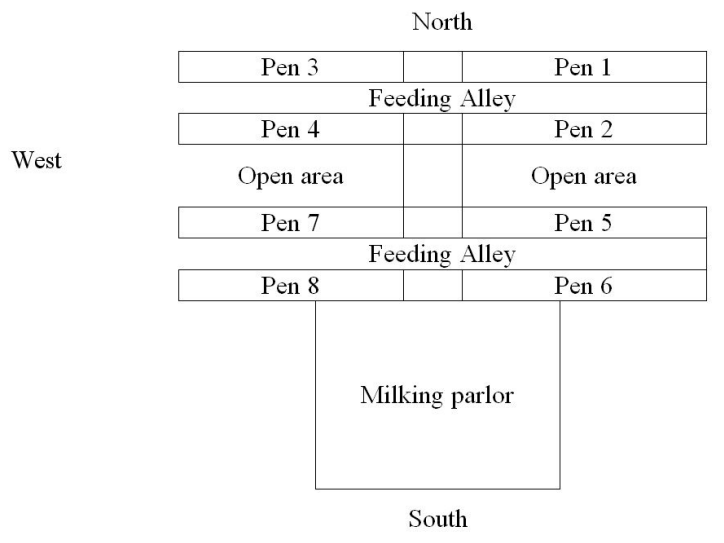

East

Figure 1. Free-stall barns layout.

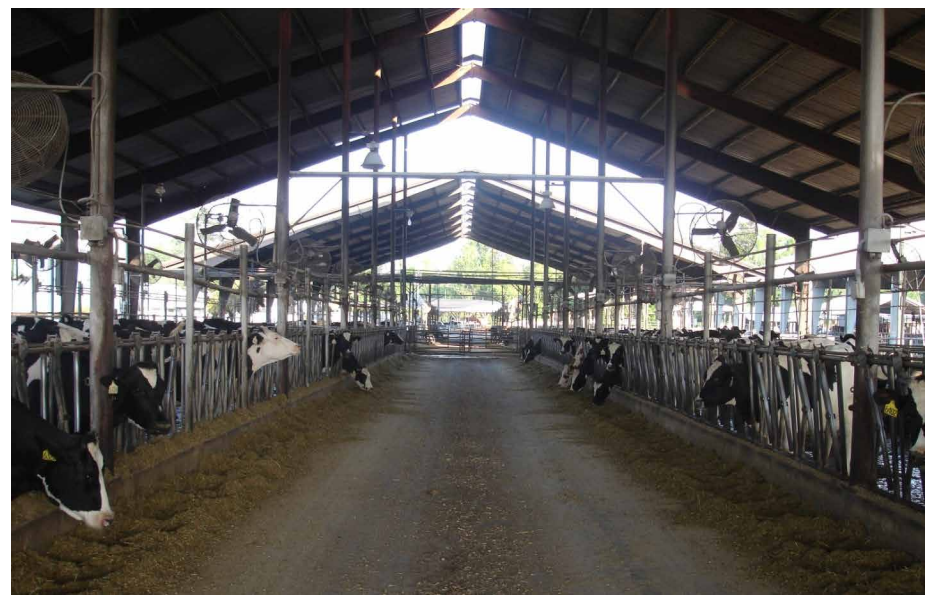

Figure 2. Picture of the barn on the south side. Credits: K. Galvão

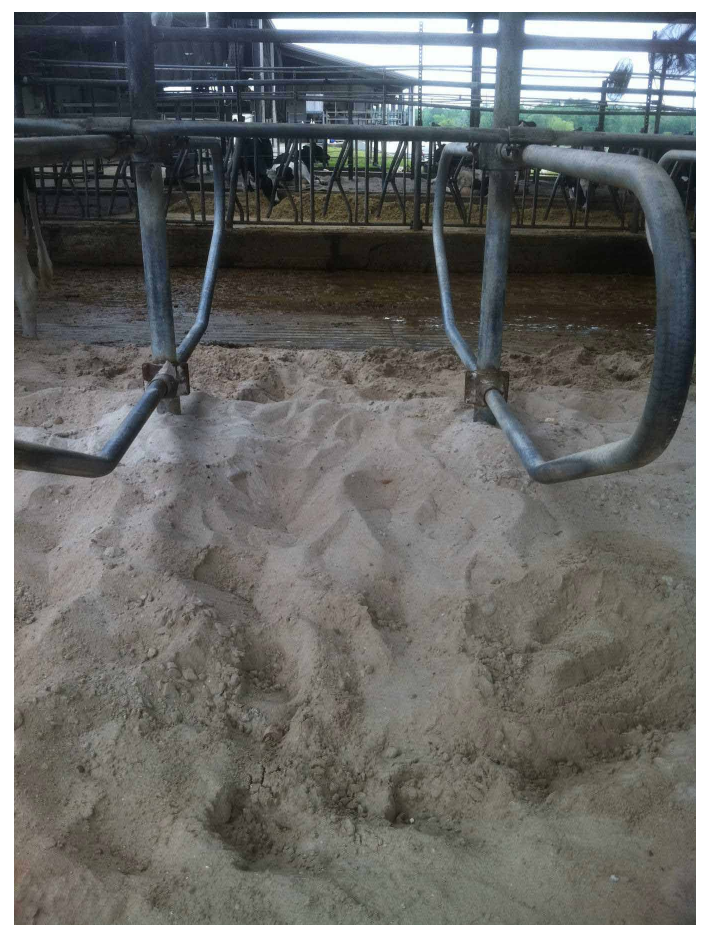

Figure 3. Sand-bedded stalls.

Credits: K. Galvão 


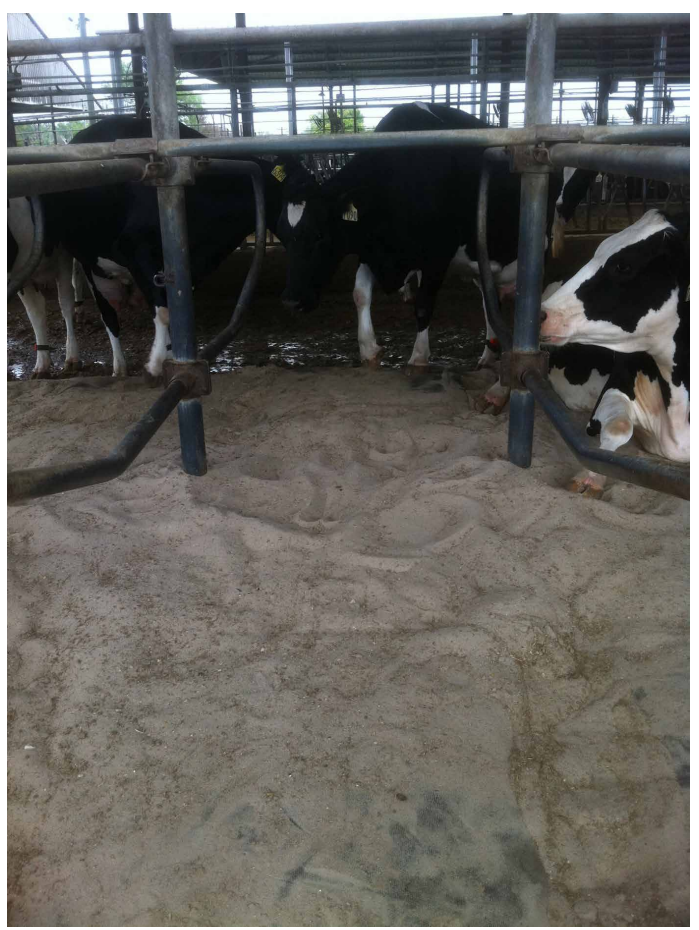

Figure 4. Waterbeds top-bedded with sand. Credits: K. Galvão

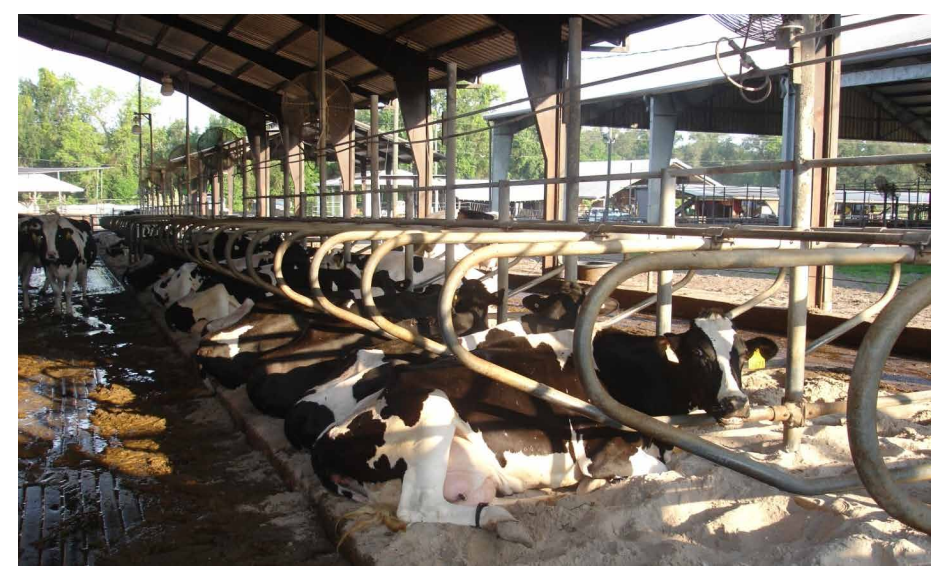

Figure 5. Cows lying in the sand-bedded stalls. Credits: K. Galvão

\section{Evaluation}

The cows from two pens with deep-bedded sand and two pens with waterbeds had their hock lesions scored and stall usage recorded. Hock lesions were scored $(0=$ no hair loss or swelling; 1 = hair loss $\geq 1.8 \mathrm{~cm}$, but no swelling; 2 $=$ swelling $\leq 7.4 \mathrm{~cm} ; 3=$ swelling $>7.4 \mathrm{~cm}$ and $/$ or purulent discharge or bleeding) as previously described by Fulwider et al. (2007) (Figure 7). Percentage of cows with lesions and percentage with each hock lesion score were calculated. Number of cows eating in the feed bunk, standing in the ally, standing with four or two feet in the stall, and lying down in stall were recorded one hour after animals returned from the morning milking as previously described by Overton et al. (2003). Stall usage was calculated by

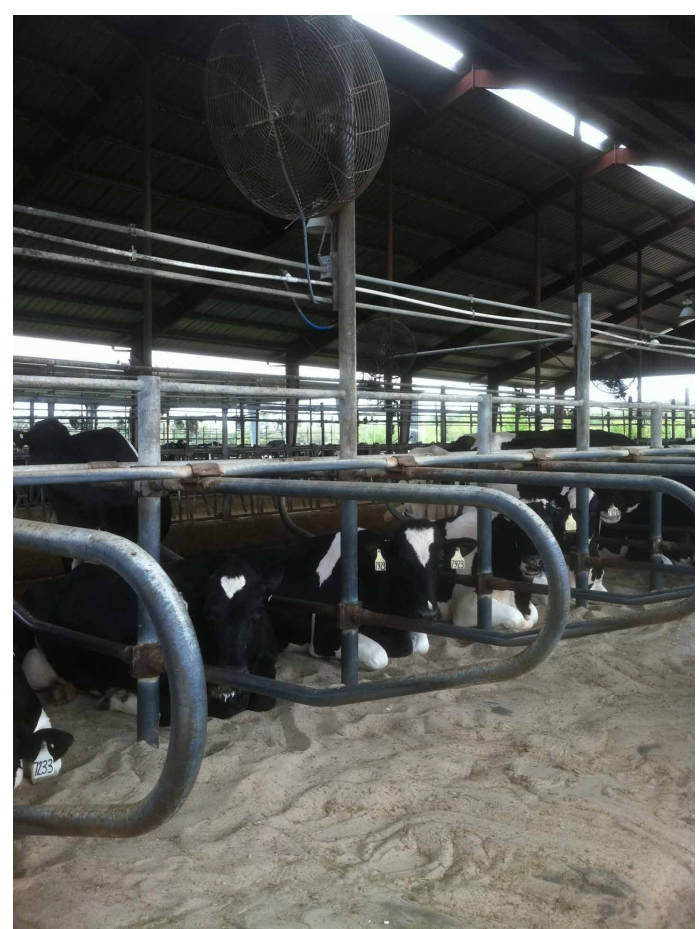

Figure 6. Cows lying in the waterbeds top-bedded with sand. Credits: K. Galvão

dividing the number of cows lying on the stalls by the total number of cow in the stalls (lying or standing).

\section{Statistical Analysis}

Percentage of cows with different lesion scores and stall usage was compared between sand beds and waterbeds using chi-square or Fisher's exact test when at least one cell number was $<5$.

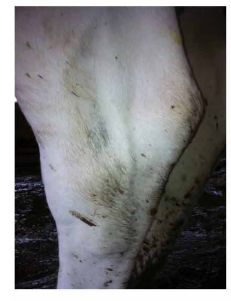

Score 0

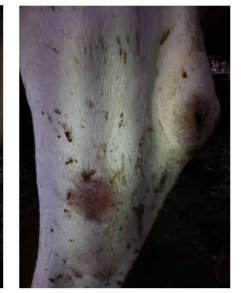

Score 1

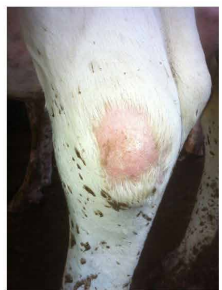

Score 2

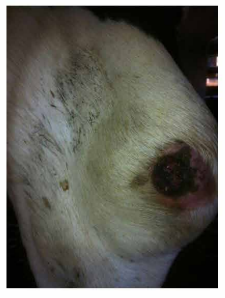

Score 3
Figure 7. Hock lesions scoring system. Credits: K. Galvão

\section{Results and Discussion}

Table 1 shows the percentage of cows with various hock lesion scores. Only $26.1 \%$ of cows in the waterbeds were free of lesions, while $91.6 \%$ of cows in the sand-bedded stalls were free of lesions (score 0 ). Furthermore, cows in sand-bedded stalls only had minor lesions (score 1), while $26.1 \%$ of cows in waterbeds had more severe lesions (score 2 ). Fortunately, only $0.6 \%$ of cows in the waterbeds had the most severe lesions (score 3 ). The differences observed in this dairy were much greater than what was reported by Fulwider et al. (2007). In that study, $75.0 \%$ of cows in sand 
beds and $64.8 \%$ of cows in waterbeds were free of lesions (score 0 ); and $22.5 \%$ of cows in sand beds and $29.8 \%$ of cows in waterbeds had minor lesions (score 1). The reason why cows at the DU have greater incidence of hock lesions is unclear, but it could be that sand rubbing against the waterbeds predisposes the cows to abrasions. The DU manager tried omitting sand as top-bedding, but stall usage decreases drastically. Another dairy we work with also tried omitting the sand top-bedding on waterbeds, but the results were disastrous, and now the dairy is bedding with compost manure.

Table 1. Influence of free-stall bed type on the percentage of cows with various lesion scores.

\begin{tabular}{|c|c|c|c|c|}
\hline \multirow[b]{2}{*}{ Stall bed type } & \multicolumn{4}{|c|}{ Lesion score, $\%^{1}$} \\
\hline & 0 & 1 & 2 & 3 \\
\hline Sand $(n=179)$ & $91.6^{\mathrm{a}}$ & $8.4^{\mathrm{a}}$ & $0.0^{\mathrm{a}}$ & 0.0 \\
\hline Waterbed $(n=161)$ & $26.1^{\mathrm{b}}$ & $47.2^{b}$ & $26.1^{b}$ & 0.6 \\
\hline \multicolumn{5}{|c|}{$\begin{array}{l}{ }^{1} 0=\text { no hair loss or swelling; } 1=\text { hair loss } \geq 1.8 \mathrm{~cm} \text {, but no } \\
\text { swelling; } 2=\text { swelling } \leq 7.4 \mathrm{~cm} ; 3=\text { swelling }>7.4 \mathrm{~cm} \text { and/or } \\
\text { purulent discharge or bleeding } \\
\text { a, b Percentages in the same column with different superscripts } \\
\text { differ }(P<0.001) .\end{array}$} \\
\hline
\end{tabular}

Table 2 shows the percentage of cows with different activity behavior one hour after returning from the milking parlor. As expected, there was no difference between sand and waterbeds in the percentage of cows eating or standing in the alleys. However, the percentage standing in the stall was greater for waterbeds compared to sand; this in turn led to decreased stall usage for waterbeds compared to sand beds. Increased percentage of cows standing in stalls with the waterbeds suggests that cows are less comfortable lying down or standing up in this bed type. The wobbly nature of the waterbeds might inhibit normal cow behavior when trying to lie down or stand up. Cows have difficulty maintaining a normal sterna lying position when lying on waterbeds; cows either slide to the side or backwards (Figure 8). Another abnormal behavior noticed was that cows lifted their front legs when lying down. Even with a good amount of sand on top of the waterbeds, cows may still not be comfortable (Figure 9). Also, several cows had lesions in their carpal joint, although this was not evaluated in the study (Figure 9).
Table 2. Influence of free-stall bed type on the percentage of cows showing different activity behavior one hour after returning from the milking parlor.

\begin{tabular}{|lcccc|}
\hline Stall bed type & \multicolumn{4}{c|}{ Activity behavior, $\%^{1}$} \\
\cline { 2 - 5 } & Eating & $\begin{array}{c}\text { Standing } \\
\text { in } \\
\text { alleys }\end{array}$ & $\begin{array}{c}\text { Standing } \\
\text { in } \\
\text { stalls }\end{array}$ & $\begin{array}{c}\text { Stall } \\
\text { usage }\end{array}$ \\
\hline Sand $(\mathrm{n}=179)$ & 10.6 & 6.2 & $7.8^{\mathrm{a}}$ & $90.6^{\mathrm{a}}$ \\
Waterbed $(\mathrm{n}=161)$ & 13.0 & 8.7 & $26.1^{\mathrm{b}}$ & $66.7^{\mathrm{b}}$ \\
\hline
\end{tabular}

${ }^{1}$ Eating $=$ number of cows eating divided by the total number of cows in the pen; standing in alleys = number of cows standing in the alley divided by the total number of cows in the pen; standing in stalls = number of cows standing in stalls divided by the total number of cows in the pen; stall usage = number of cows lying in the stalls divided by the number of cows in the stalls (standing or lying).

$a, b$ Percentages in the same column with different superscripts differ $(P<0.001)$.

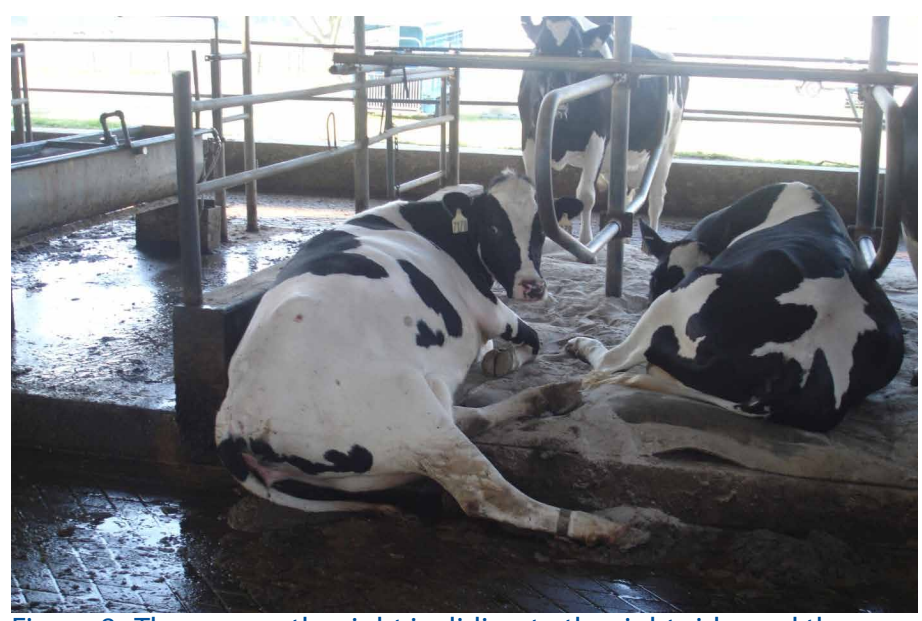

Figure 8 . The cow on the right is sliding to the right side, and the cow on the left is sliding backwards. Credits: K. Galvão

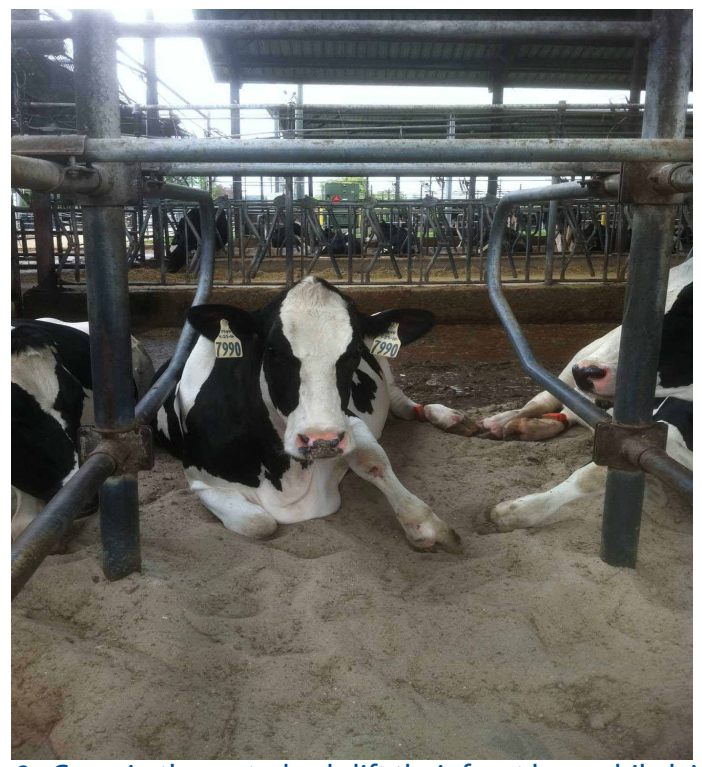

Figure 9. Cows in the waterbeds lift their front legs while lying down. The cow in the center also has a carpal joint lesion. Credits: K. Galvão 


\section{Conclusion}

Choosing the most appropriate stall bed type is an important management decision that can affect cow comfort, health, welfare, and productivity, all of which contribute to overall farm profitability. Most types of beds can meet the cow's needs for comfort and welfare, but producers should carefully consider stocking density, stall dimensions, quality of bedding material, and frequency of re-bedding. If you plan to use a certain type of bedding, you should visit dairies that use the stall bed type you plan to install in order to prevent unwanted consequences. This study only included one dairy, but we observed that when stalls are maintained at optimal conditions, cows in sand-bedded stalls had decreased incidence of hock lesions and increased stall usage compared to cows in waterbeds. Further controlled side-by-side studies are necessary to confirm our findings and compare waterbeds with other types of bedding.

\section{References and Resources}

American Medical Association. 2004. "Instructions for Authors: Système International (SI) Conversion Table." JAMA 291: 125-9. http://jama.ama-assn.org/cgi/content/ full/291/1/125/DC6.

Andersson, L. 1988. "Subclinical Ketosis in Dairy Cows." Vet. Clin. North Am. Food Anim. Pract. 4 (2): 233-48.

Cook, N.B. 2012. "Cow Comfort and Health." Accessed April 2013. http://www.extension.org/pages/26035/ cow-comfort-and-health.

Fulwider, W. K., T. Grandin, D. J. Garrick, T. E. Engle, W. D. Lamm, N. L. Dalsted, and B. E. Rollin. 2007. "Influence of Free-Stall Base on Tarsal Joint Lesions and Hygiene in Dairy Cows." J. Dairy Sci. 90 (7): 3559-66.

Gomez, A., and N. B. Cook. 2010. "Time Budgets of Lactating Dairy Cattle in Commercial Freestall Herds." J. Dairy Sci. 93 (12): 5772-81.

Overton, M. W., D. A. Moore, and W. M. Sischo. 2003. "Comparison of Commonly Used Indices to Evaluate Dairy Cattle Lying Behavior," In Proc. Dairy Housing Conf., Fort Worth, TX, edited by K. Janni, 125-130. St. Joseph, MI: Amer. Soc. Agric. Engineers.

USDA. 2009. Dairy 2007, Part IV: Reference of Dairy Cattle Health and Management Practices in the United States. Washington, D.C.: United States Department of Agriculture, Animal and Plant Health Inspection Service. http://www.aphis.usda.gov/animal_health/nahms/dairy/ downloads/dairy07/Dairy07_dr_PartIV.pdf. 